\title{
Physical and Chemical Properties of Volcanic Ejecta Produced by the Eruption of Mt. Kirishima Shinmoe- dake, Japan -A Case Study After the Explosive Eruption on March 25, 2018-
}

Hiromi Akita ( $\square$ akita@bosai.go.jp )

National Research Institute for Earth Science and Disaster Prevention https://orcid.org/0000-0002$1135-1514$

\section{Research Article}

Keywords: Particle size distribution, Infiltration capacity , Soil test, Volcanic ejecta, Volcanic eruption

Posted Date: February 10th, 2021

DOl: https://doi.org/10.21203/rs.3.rs-169426/v1

License: (c) (1) This work is licensed under a Creative Commons Attribution 4.0 International License. Read Full License 
1 Physical and chemical properties of volcanic ejecta produced by the eruption of Mt.

2 Kirishima Shinmoe-dake, Japan -A case study after the explosive eruption on

3 March 25, 2018-

4

5 Hiromi Akita a*

6 a National Research Institute for Earth Science and Disaster Resilience

$7 \quad$ akita@bosai.go.jp *corresponding author

8

9

10 Keywords: Particle size distribution; Infiltration capacity; Soil test; Volcanic ejecta;

11 Volcanic eruption 
14 The purpose of this study was to clarify the physical and chemical properties of

15 volcanic ejecta that fell after the explosive eruption on March 25, 2018 at Shinmoe-

16 dake. In order to investigate the infiltration capacity, which is one of the physical

17 properties of volcanic ejecta, plots were set up on the outer forest plain, the forest

18 plain, and the forest talus, and a cylindrical frame test was conducted with reference to the method of Takeshita (2011). In addition, soil samples were collected at the three locations where the cylindrical frame test was conducted. The final infil-

21 tration capacity of $38-92 \mathrm{~mm} / \mathrm{h}$ appeared lower in the forest talus than in the forest plain. It is considered that this is due to the small particle size distribution

23 of $0.1 \mathrm{~mm}$ or more, regardless of the particle size of the silt / clay particle size

24 classification. When the chemical properties of the collected volcanic ejecta were 
examined, $\mathrm{Ca}$ and $\mathrm{SO}_{4}$ were contained at high values. Since these compounds be-

26 come the source of gypsum that reduces infiltration capacity when they react with water, it has become clear that they have the potential to contribute to the generation of debris-flow as a chemical property. 


\section{Introduction}

years from January 26-27, 2011, and volcanic ejecta was deposited in the mountain

stream at the foot of the mountain (Oikawa et al. 2013). The deposition of fine-

grained volcanic ejecta on slopes is said to significantly reduce the infiltration ca-

pacity (Onda et al. 1996), which increases the risk of debris flow generation. At the

36 time of the eruption in January 2011, there was a risk of a debris flow disaster after rainfall, so the Ministry of Land, Infrastructure, Transport and Tourism conducted a survey (Ministry of Land, Infrastructure, Transport and Tourism Sabo Department 2011-2018). The eruption at this time entered the lull state in September 2011, but an explosive eruption occurred again on October 11, 2017 (Ministry of Land, Infrastructure, Transport and Tourism Sabo Department 2011-2018). 
42 After that, the eruption continued until April 2018, and volcanic ejecta was accu-

43 mulated in the mountain stream at the foot of the mountain. According to Koi et

44 al. (2017), although a sediment outflow was seen, it was directly linked to human

45 damage. No occurrence of debris flow was confirmed. In order to understand the

46 risk of debris flow associated with rainfall after volcanic ejecta fall, it is necessary

47 to conduct a field survey of physical and chemical properties that are soil charac-

48 teristics of volcanic ejecta, unlike the amount of rainfall that can be collected on a

49 desk. However, since the field survey immediately after the eruption is dangerous,

50 the range of people entering is limited, and it is difficult to collect data after the

51 eruption. Therefore, the survey results of volcanic ejecta immediately after the eruption are extremely valuable, and it is expected that accumulating the soil qual-

53 ity data will be academically meaningful and useful for predicting debris flow 
54 disasters after the volcanic eruption. Looking at the research examples of the eruption of Mt. Shinmoe-dake in Japan,

56 after the eruption in January 2011, the physical and chemical properties of vol-

57 canic ejecta were investigated at the foot of Mt. Shinmoe-dake, and the relationship with the deposition thickness of volcanic ash was considered. (Kisa et al. 2011 / Shimizu et al. 2011 / Koi et al. 2013). On the other hand, regarding the eruption

60 after October 2017, although the actual condition of sediment runoff has been in-

61 vestigated by Koi et al. (2017), there are few cases in which the physical and chem-

62 ical properties of volcanic ejecta were investigated. Therefore, the purpose of this

63 study is to clarify the actual physical and chemical properties of volcanic ejecta

64 that fell after the explosive eruption on March 25, 2018 at Shinmoe-dake, Japan. 


\title{
2. Methods
}

67

68

69

70

refers to the result reported by the Ministry of Land, Infrastructure, Transport and

71 Tourism Sabo Department (2011-2018). The research date of this study is March

\subsection{Survey site}

shima City, Kagoshima Prefecture (Fig. 1). The ash thickness as of March 6, 2018

The survey sites are located at the foot of Mt. Shinmoe-dake located in Kiri-

\author{
Tourism Sabo Department (2011-2018). The research date of this study is March
}

26, the day after the explosive eruption on March 25, 2018. It is assumed that the

73 deposition status of volcanic ejecta will differ depending on the presence or absence

74 of a cover such as a crown on the ground surface. Therefore, it was decided to com-

75 pare inside and outside the forest. For information on the eruption date and scale

76 of Mt. Shinmoe-dake, refer to the Ministry of Land, Infrastructure, Transport and

77 Tourism Sabo Department (2011-2018). For rainfall, I collected the observation 
values at Yadake Rainfall Observatory of the Ministry of Land, Infrastructure,

79 Transport and Tourism, which is located near the survey site.

80

81

\subsection{Infiltration capacity survey}

82

In order to investigate the infiltration capacity, which is one of the physical

83

properties of volcanic products, three plots are set at each of the three locations

84 (outer forest plain, forest plain, and forest talus), and the method of Takeshita

85 (2011) is referred to. As a result, a cylindrical frame test was conducted (Photo 1

(a) - (h)). Cylindrical frame test is a cylindrical frame $(\varphi=100 \mathrm{~mm}, \mathrm{~L}=150 \mathrm{~mm})$ of about $300 \mathrm{~mm}$ inserted into the surface covered with volcanic ejecta, and water

88 injection is continued for a certain period of time. Is to measure. Since this test 
cylindrical frame, Takeshita (2011) presents the coefficient according to Equation

(1) and shows the correction of the real value. In this study as well, the method was quoted and the measurement value of the cylindrical frame was corrected by Equation (1). Real infiltration capacity $(\mathrm{mm} / \mathrm{h})=0.24 \cdot$ cylindrical frame infiltration value measurement, but gradually becomes slower in the latter half of the measurement (Takeshita 2011). The test was continued until the permeation rate became slow,

100 and the test was terminated when the change was visually confirmed. In this study,

101 the measured value at this time was defined as the final osmotic permeability 

physical properties, soil particle density, ratio of silt and clay, and particle size disvalue and used for the analysis.

\subsection{Soil test}

at the location where the cylinder frame test was conducted, soil cylinder samples

(100 cc) were collected at the three locations plotted at the three locations. For

tribution were measured. The soil test procedure was in accordance with Japanese

110 Industrial Standards (A1202, A1203, A1204).

In addition, an X-ray diffraction test was conducted to investigate the type of

112 minerals in the fine-grained volcanic ash deposited on the ground surface. An X-

113 ray diffraction tester (MultiFlex, $40 \mathrm{kV}, 40 \mathrm{~mA}$, manufactured by Rigaku Denki 
114 Kogyo Co., Ltd.) was used, and measurement was performed using Cu-a rays. Min-

115 eral determination was performed based on the data obtained in this test.

116 The chemical properties of water-soluble ions $\left(\mathrm{Na}, \mathrm{K}, \mathrm{Ca}, \mathrm{Mg}, \mathrm{Cl}, \mathrm{SO}_{4}, \mathrm{NO}_{3}\right.$,

$117 \mathrm{NH}_{4}$ ) were measured by the water-soluble amount test, which is one of the chemi-

118 cal analysis methods (JGS 0241-2009). K, Ca, Mg, and Cl were measured with an

119 atomic absorption spectrophotometer (ZA-3000, Hitachi, Ltd.) using the eluate.

$120 \mathrm{SO}_{4}, \mathrm{NO}_{3}$ and $\mathrm{NH}_{4}$ were measured using an ion chromatograph (ICA-2000, Toa

121 DKK). sample, centrifuge the sample solution, and read the wavelength of $285.2 \mathrm{~nm}$ using an atomic absorption spectrophotometer (Hitachi ZA-3000). It was measured. For exchangeable Ca, use the sample solution (100 mL) filtered by CEC measurement, 
set the wavelength of atomic absorption spectrophotometer (Hitachi ZA-3000) to

$127422.7 \mathrm{~nm}$, calculate the calcium concentration, and determine the content rate in

128 volcanic ash. The same applies to exchangeable $\mathrm{Na}$, using the sample solution (100

$129 \mathrm{~mL}$ ) filtered by the CEC measurement, setting the wavelength of the atomic ab-

130 sorption spectrophotometer (Hitachi Ltd. ZA-3000) to $589.0 \mathrm{~nm}$, and obtaining the

131 sodium concentration. The content rate was calculated. The ratio of exchangeable

132 ions to cation exchange capacity expressed as a percentage is called ESP (Ex-

133 changeable Sodium Percentage) (Agassi et al. 1981), and can be calculated using

134 Equation (2). The volcanic ejecta are known to show high values, and it is said that

135 in soils of 1.5 or above, chemical crusts are formed with rainfall and the infiltration

136 capacity decreases (Gal et al. 1984). 


\section{Results and discussion}

\subsection{Eruption status and rainfall status since October 2017}

143 day before the survey day (March 25, 2018), and it was confirmed that fresh fine-

144 grained volcanic ash had accumulated around the survey site (Photo 1). Since the

145 eruption on October 11, 2017, the 24-hour rainfall has been decreasing until De-

146 cember 2017, and then increasing toward February 2018. Looking at the hourly

147 rainfall, 12 times recorded $10 \mathrm{~mm} / \mathrm{h}$ or more, and only 3 times recorded $20 \mathrm{~mm} /$

$148 \mathrm{~h}$ or more. Also, on March 5, 2018, it recorded a maximum of about $36 \mathrm{~mm} / \mathrm{h}$

149 during the eruption period. It can be confirmed that there was $10 \mathrm{~mm} / \mathrm{h}$ or more 
150 of rainfall per hour after the eruption, regardless of the time of the eruption, but

$15120 \mathrm{~mm} / \mathrm{h}$ or more occurred twice (22 mm / h: April 14, 2018, $20 \mathrm{~mm} / \mathrm{h}$ : April 24

152 of the same year). Therefore, it is estimated that there was no heavy rainfall of 20

$153 \mathrm{~mm} / \mathrm{h}$ or more immediately after the eruption of Mt. Shinmoe-dake.

\subsection{Physical properties of volcanic products}

Fig. 3 shows the time course of the real infiltration capacity. In the forest plain,

157 the infiltration into the ground was too fast and it was not possible to measure it

158 properly, so the comparison is between the forest plain and the forest talus. Both

159 the plain outer the forest and the talus in the forest have been tested three times.

160 Comparing the real infiltration capacity, the talus in the forest tends to be lower

161 than the plain in the forest. In addition, when we look at the time when the real 
162 infiltration capacity begins to decline, the outer plains are faster than $1000 \mathrm{sec}$,

163 while the inner talus tend to be slower. Looking at the 1-hour rainfall data (Fig. 2)

164 at the Yadake Rainfall Observatory of the Ministry of Land, Infrastructure,

165 Transport and Tourism near the survey site, it recorded a maximum of about 36

$166 \mathrm{~mm} / \mathrm{h}$ (March 5, 2018), but on this day Before the explosive eruption. Next, the

167 rainfall with an hourly rainfall is 2 times $(22 \mathrm{~mm} / \mathrm{h}:$ April 14, 2018, $20 \mathrm{~mm} / \mathrm{h}$ :

168 April 24, the same year), which recorded more than $20 \mathrm{~mm} / \mathrm{h}$. Comparing the real

169 infiltration capacity at the end of the period after 1000 seconds, it was about $74^{-}$

$170184 \mathrm{~mm} / \mathrm{h}$ on the outer forest plain and about $38-92 \mathrm{~mm} / \mathrm{h}$ on the forest talus,

171 showing values larger than the hourly rainfall. It became clear that there was.

172 This is consistent with the fact that no debris flow occurred at the foothills of Mt.

173 Shinmoe-dake. 
175 soil particle density. The smaller the $\mathrm{D}_{50}$ of volcanic ejecta, the higher the soil par-

176 ticle density (Fig. 4 (a)). In addition, the higher the soil particle density, the lower

177 the infiltration capacity tends to be (Fig. 4 (b)). Generally, when the particle size of

178 the soil particles is small, the voids between the soil particles in the soil are small

179 and the density is high, so that it becomes difficult for water to infiltration into the

180 ground. From this, it is considered that the soil particle density increased and the

181 final infiltration capacity decreased because the volcanic ejecta with small grain

182 size were deposited on the forest talus. From this, it is speculated that since the

183 volcanic ejecta with a small grain size are deposited on the talus in the forest, the

184 soil particle density is reduced and the final infiltration capacity is low (Fig. 5 (a)

185 and Fig. 5 (b)). Furthermore, regarding the ratio of silt and clay, when the 
relationship between $\mathrm{D}_{50}$ and soil particle density was examined, no correlation

187 was found between the two. Therefore, regardless of the proportion of fine particles

188 such as silt and clay, it is suggested that the size of soil particles is generally small

189 and that the real infiltration capacity of the end of the talus in the forest has decreased. Next, Fig. 6 shows the particle size distribution of the collected sample, and Table 1 shows the basic information and measured values. In addition, the grain size of the talus in the forest in this study tends to be smaller than that in

193 the outer forest plain or the forest plain. From these facts, it is suggested that the

194 smaller particle size of the particle size category of $0.1 \mathrm{~mm}$ or more than the par-

195 ticle size category of silt / clay may contribute to the decrease of the final infiltra-

196 tion capacity.

Fig. 7 shows the relationship between the $\mathrm{D}_{50}$ and silt-clay ratios and the final 
198 infiltration capacity. Looking at the results of this study, the lower the $\mathrm{D}_{50}$, the

199 lower the final infiltration capacity tends to be $(R=0.69, p=0.04)$. Next, looking

200 at the ratio of silt / clay, it can be seen that the real infiltration capacity at the end

201 of the period tends to decrease slightly as it increases, but the variation is large ( $R$

$202=0.50, p=0.17)$. This suggests that the $\mathrm{D}_{50}$ index, which represents the particle

203 size distribution, may represent a tendency for the final infiltration capacity.

\subsection{Chemical properties of volcanic products}

In order to study the chemical properties, we first clarify the mineral composi-

207 tion of the volcanic products by X-ray diffraction test. Fig. 8 shows the composition

208 of minerals by X-ray diffraction test. First, the mineral that appears in the peak of

209 the X-ray diffraction test of the sample collected in this study is Anorthite. Other 
minerals detected include Enstatite, Augite, and Ilmenite, but no gypsum that

211 causes a decrease in infiltration capacity when fine-grained volcanic ash solidifies.

212 The survey of this study collected fresh volcanic ash that had fallen after the ex-

213 plosive eruption on March 25, 2018, but there was almost no rainfall within a week

214 before the survey (Fig. 2). It is speculated that no gypsum was detected as a result

215 of no chemical reaction between the deposited volcanic ash and water.

216 Table 2 shows the ion amount and exchangeable base amount of the collected

217 volcanic ejecta. Looking at the amount of detected ions, it can be seen that com-

218 pounds that are the main components of gypsum, such as $\mathrm{Ca}$ and $\mathrm{SO}_{4}$, are con-

219 tained in high values.

220 Looking at the amount of exchangeable base in this study, a high value of $52.5 \%$ is

221 shown (Table 2). Onda et al. (1996) calculated ESP by the same method by Mt. 
Unzen Fugen-dake from June 1990 to June 1995 within the eruption period from

223 November 1990 to March 1995. Mt. Unzen Fugen-dake has frequently had debris

224 flows associated with rainfall since 1991, and this study reported a high value of

$2258.6-76.5 \%$ up to a depth of $2 \mathrm{~cm}$ on the surface layer of volcanic ash. Comparing the

226 ESP values of this study with the results of Onda et al. (1996), the volcanic ash of

227 Shinmoe-dake may have the potential to reduce infiltration capacity. In connection

228 with this, when water was sprinkled on the forest talus after the cylindrical frame

229 test and the surface of the volcanic ejecta was observed (Photo 2), fine-grained vol-

230 canic ash began to solidify, causing debris flow. It has been confirmed that a surface

231 flow has occurred. From the above, the volcanic ejecta of Shinmoe-dake after the

explosive eruption on March 25, 2018 will solidify and become gypsum when there

233 is a large amount of rainfall, and the infiltration capacity will decrease, 
235 of doing so.

\section{Conclusion}

239 ejecta that fell after the March 25, 2018 explosive eruption, albeit with a limited

240 sample size. I would like to continue to accumulate soil data on the physical and

241 chemical properties of volcanic ejecta by conducting similar surveys on volcanic eruptions.

\section{Acknowledgment}

245 The hourly rainfall observed at Yadake rainfall observatory near Mt. Shinmoe- 
dake was provided by Miyazaki river national highway office, Ministry of land,

247 infrastructure, transport and tourism. For the soil test, I cooperated with Urban

248 soil research Co., Ltd. and had a meaningful discussion when interpreting the data.

249 This research analyzed part of the content when the author was in the Public

250 Works Research Institute, and with the help of Mr. Naoki Fujimura of the Public

251 Works Research Institute (at that time), it was greatly supported. Finally, I would

252 like to thank these people.

255 Agassi, M., Shainburg, I., Morin, J., 1981. Effect of electrolyte concentration and

256 soil sodicity on infiltration rate and crust formation, Soil Science, 45, 848-851.

257 Gal, M., Agcan, L., Shainberg, I., Keren, R., 1984. Effect of exchangeable sodium 
and phosphogypusum on crust structure-scanning electron microscope observa-

259 tion, Soil Science Society of America J, 48, 872-878.

260 Geological Survey of Japan, AIST., 2017. Mt. Kirishima (Shinmoe-dake) October

2612017 Analysis of constituent minerals of volcanic ash, volcanic eruption predic-

262 tion liaison website, https://www.gsj.jp/hazards/ volcano / kazan-bukai / yochiren

263 / kirishima_20171023_3.pdf.

264 Kisa, H., Yamakoshi, T., Ishizuka, T., Sugiyama, M., Takiguchi, S., 2013 The fea-

265 ture of surface runoff caused by rainfall on hillslopes covered with the tephra by

266 the 2011 Eruption of Shinmoe-dake, Kirishima Volcano, J of the Jpn Society of

267 Eros Control Engineering, 65 (6), 12-21.

268 Koi, T., Fujisawa, Y., Fujita, K., Anyoji, N., Takiguchi, S., Sugiyama, M., 2013.

269 Characteristics of juvenile pyroclastic materials affected on runoff and sediment 
271 Society of Eros Control Engineering, 65 (6), 37-45.

272 Koi, T., Egashira, I., Suzuki, T., Anyoji, N., 2018 Sediment discharge from a for-

273 ested-mountain watershed affected by volcanic ashfall during the 2011 eruptions

274 of Shinmoe-dake, J of the Jpn Society of Eros Control Engineering, 70 (6), 24-33.

275 Large-scale eruption measures working group for large-scale eruption, Cabinet Of-

276 fice, 2018. Characteristics of volcanic ash, published online, http://www.bou-

277 sai.go.jp/kazan/kouikikouhaiworking/pdf/20181207siryo2.pdf.

278 Ministry of Land, Infrastructure, Transport and Tourism Sabo Department., 2011-

279 2018. Response to eruptive activity of Mt. Shinmoe-dake, web publication,

280 http://www.mlit.go.jp/mizukokudo/sabo/volcanic_sabo_shinmoe.html.

281 Oikawa, T., Tsutsui, M., Tajima, Y., Shibahara, A., Furukawa, R., Saito, M., Ikebe, 
- Bora (pumice stone) is falling! eruption of Mt. Shinmoe-dake, Kirishima vol-

Shimizu, S., Jitosono, T., Shimokawa, E, Yamakoshi, T., Kisa, H., Takiguchi, S.,

Takeshita, K., 2011. Physical composition of soil surface infiltration capacity and 

vegetation (II), Water Science, 317, 52-83. 
Figures

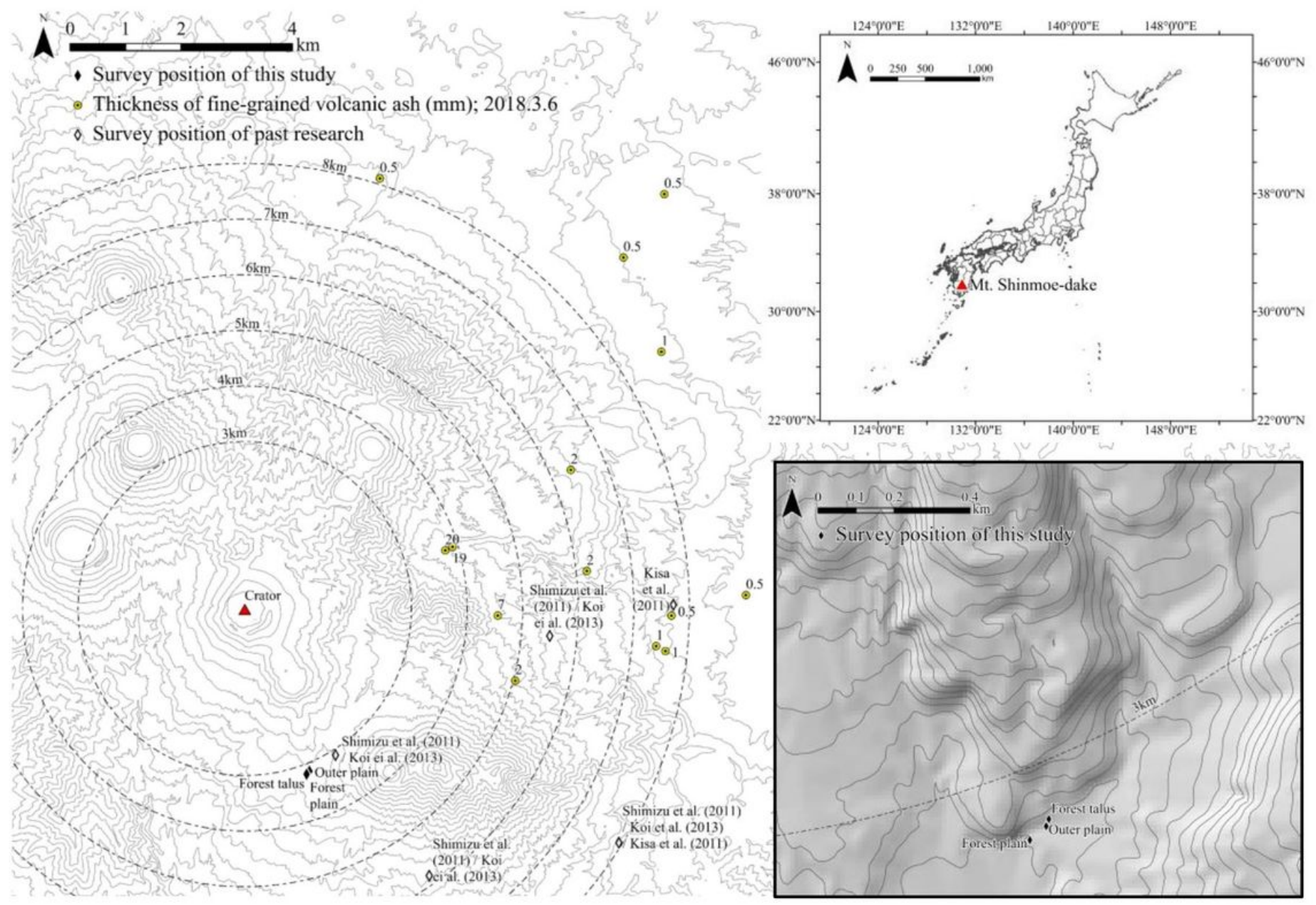

Figure 1

Relationship between distance from Mt. Shinmoe-dake crater and survey I ocation 


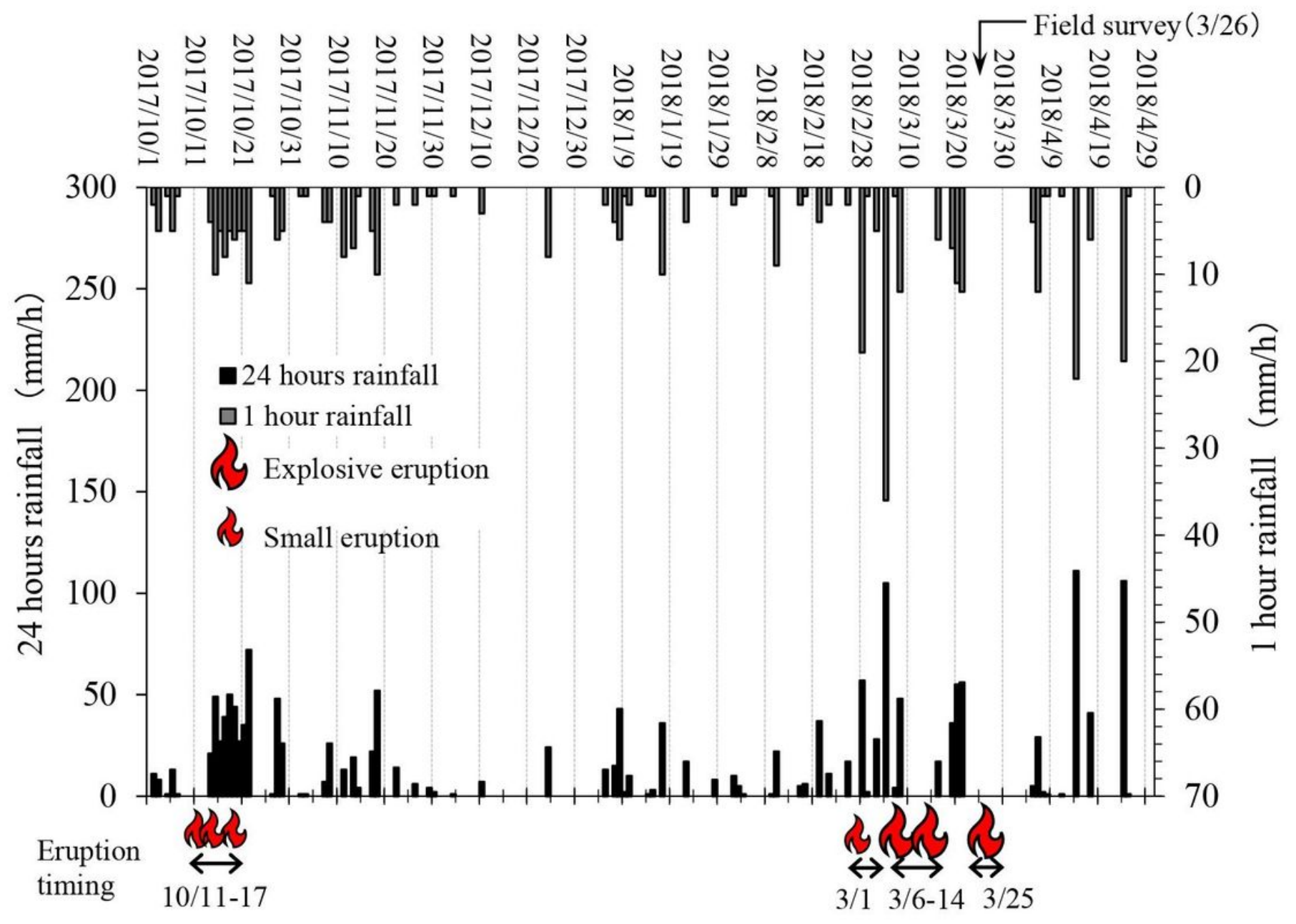

Figure 2

Eruption time of Mt. Shinmoe-dake and hourly rainfall 
(a)

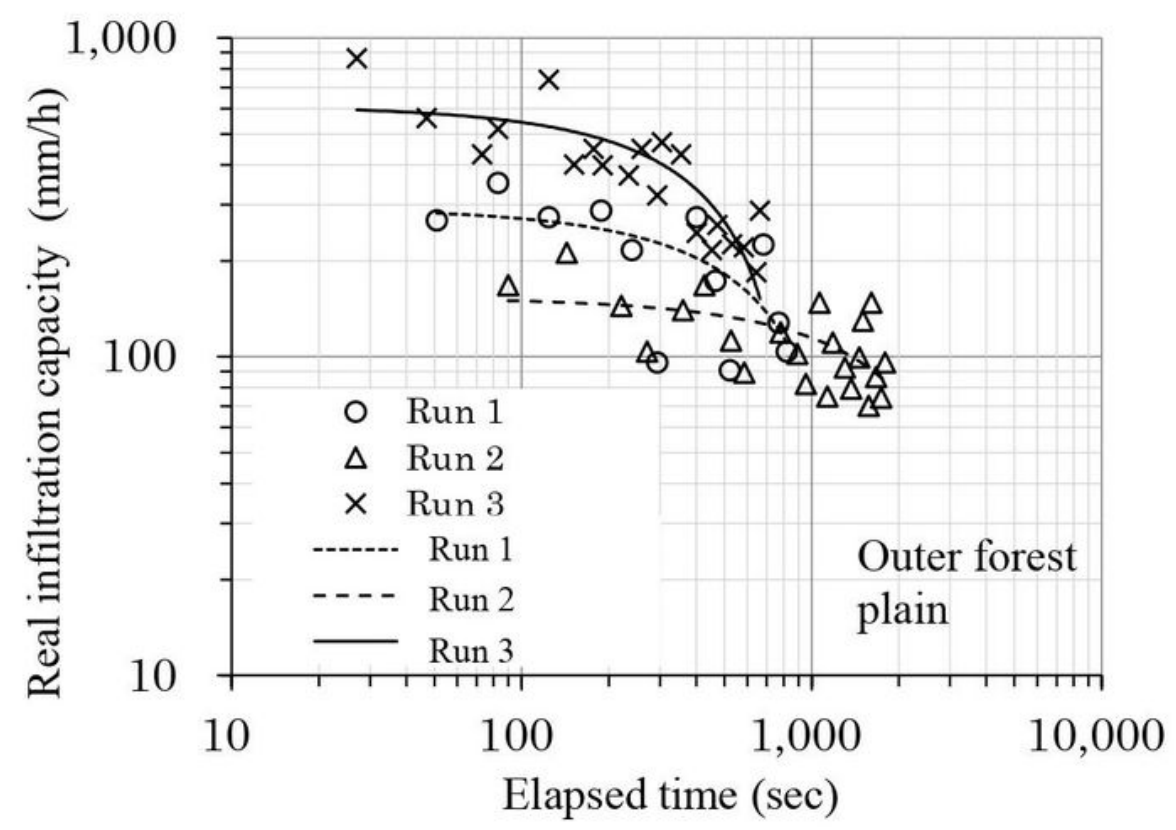

(b)

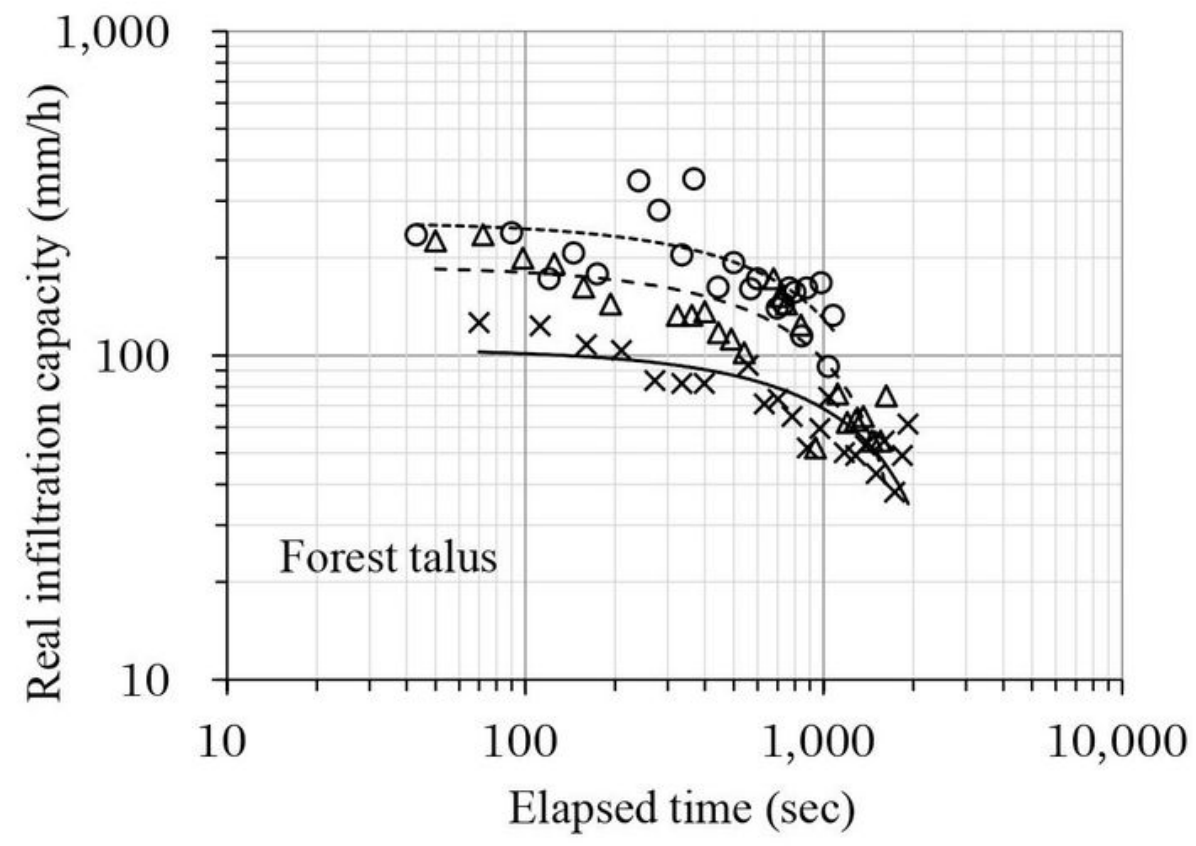

Figure 3

Time-dependent change in real infiltration capacity 
(a)

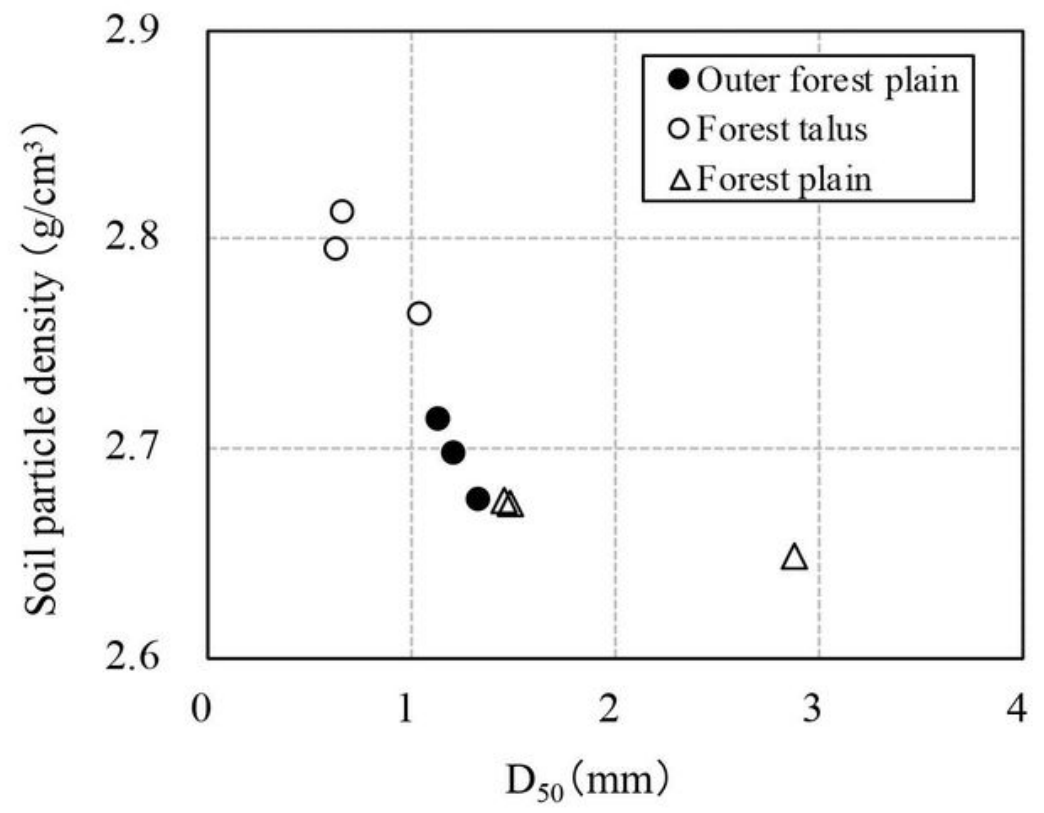

(b)

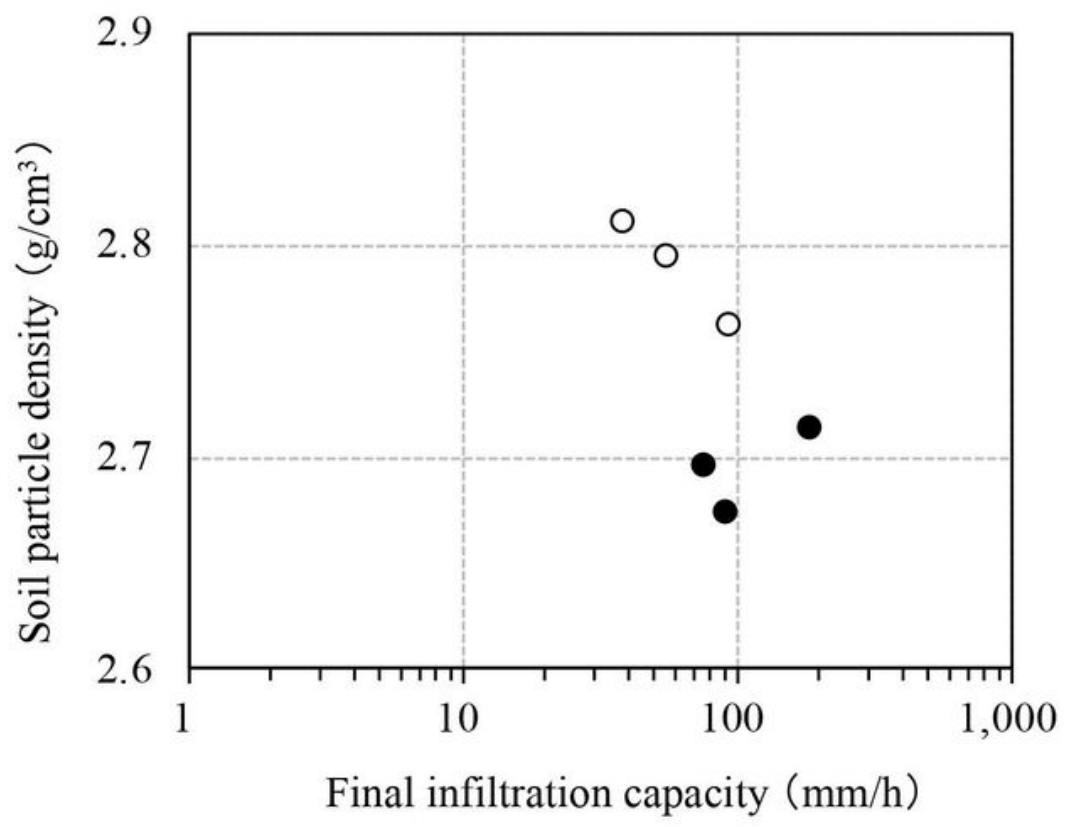

Figure 4

Relationship between D50 and final infiltration capacity and soil particle d ensity 
(a)

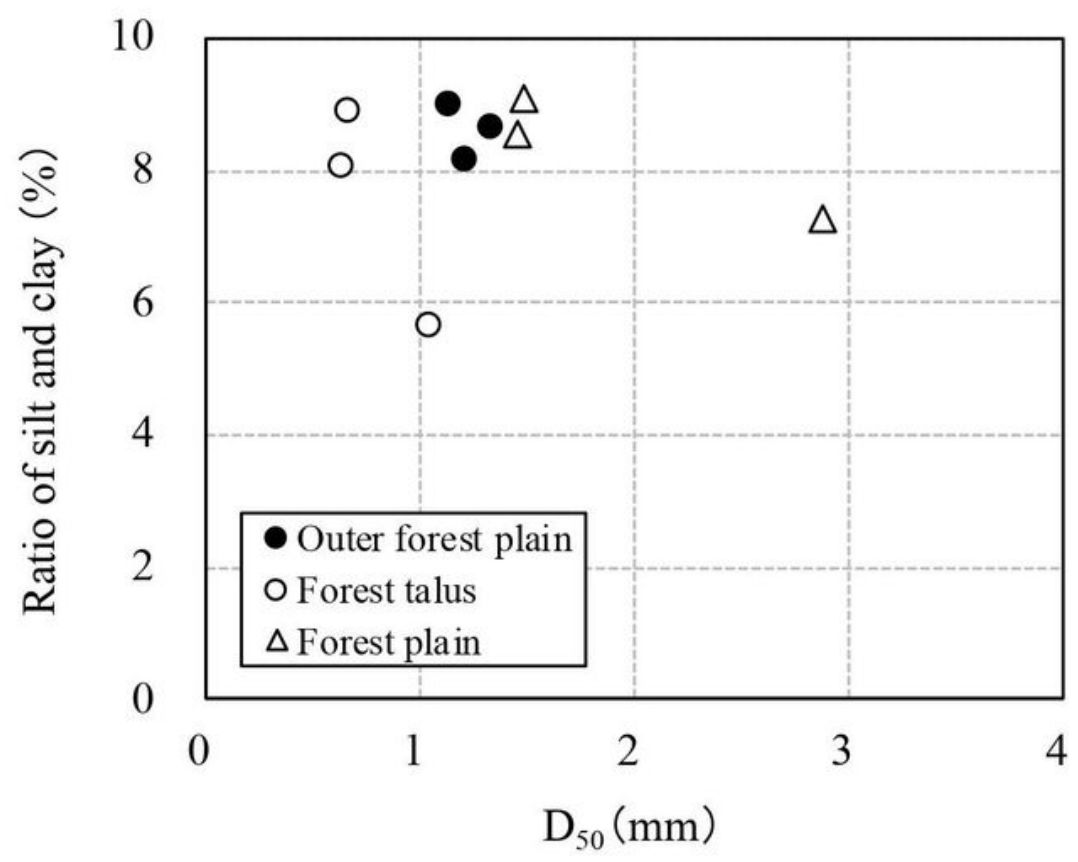

(b)

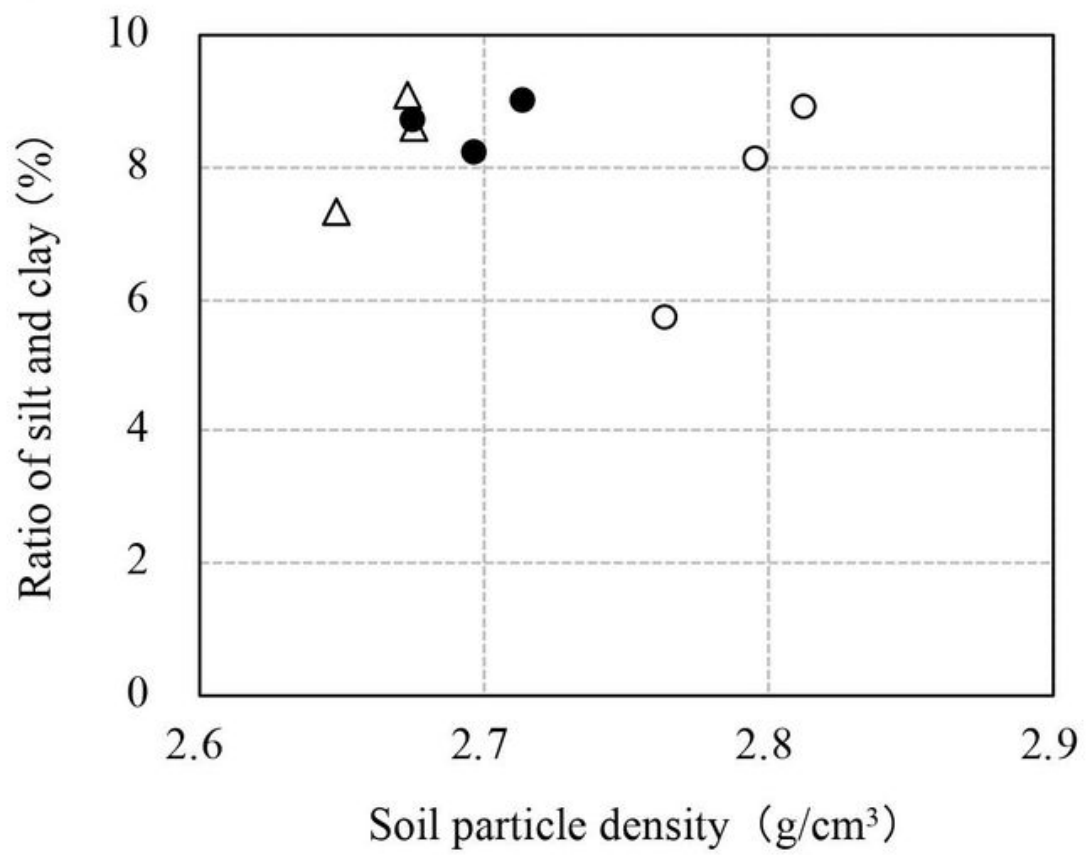

Figure 5

Relationship between D50 and soil particle density and ratio of silt and cla y 


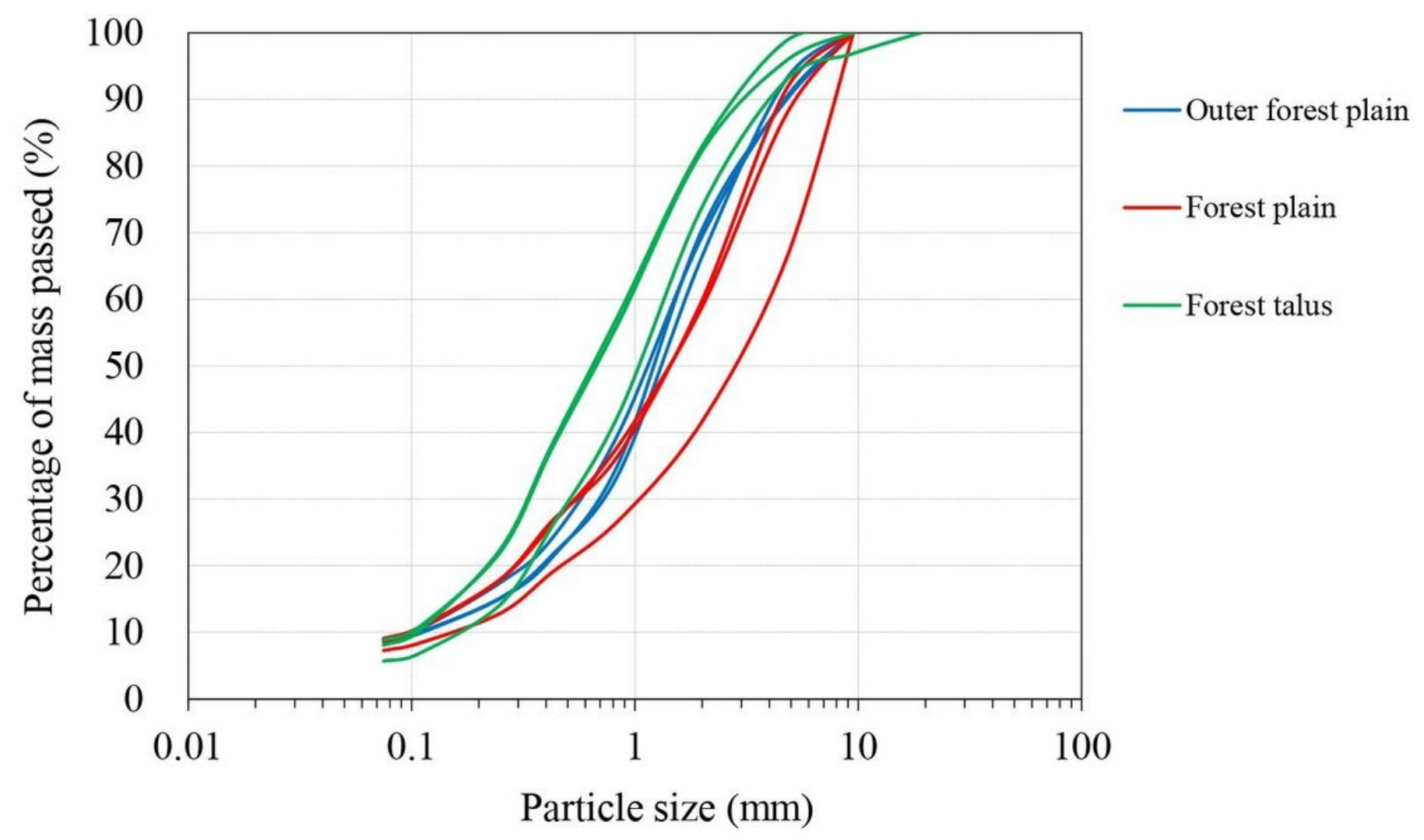

Figure 6

Particle size distribution of collected sample 
(a)

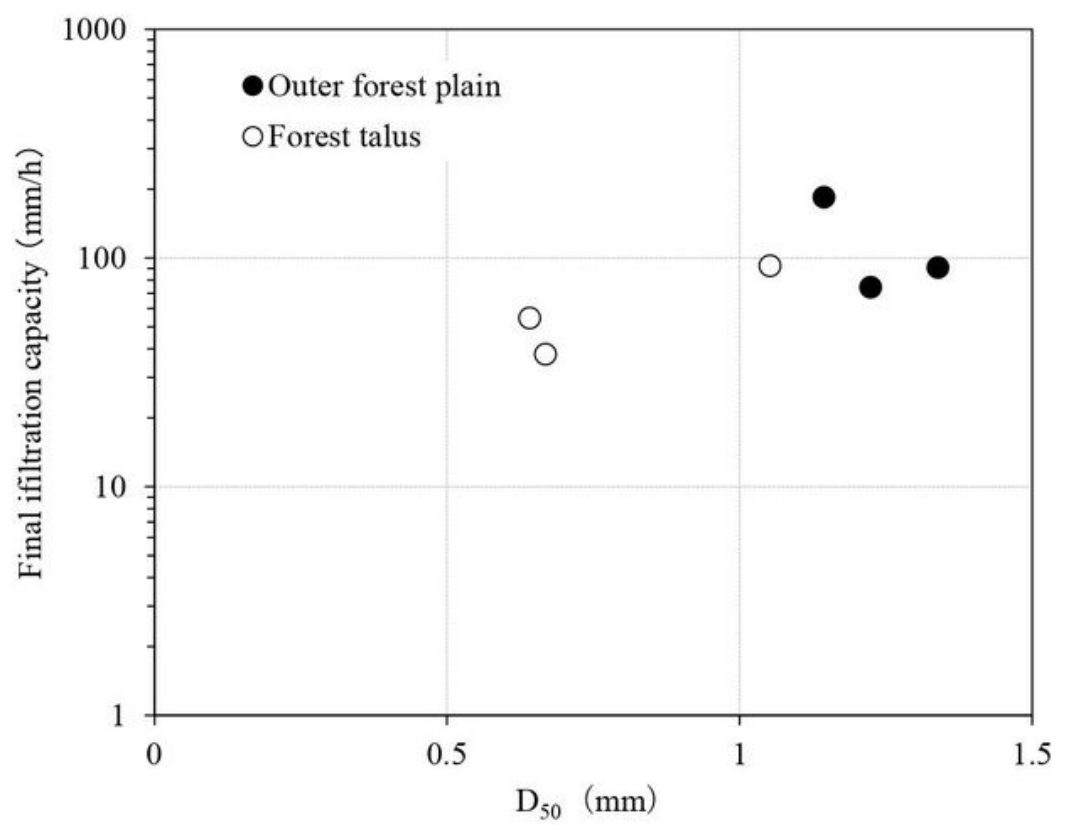

(b)

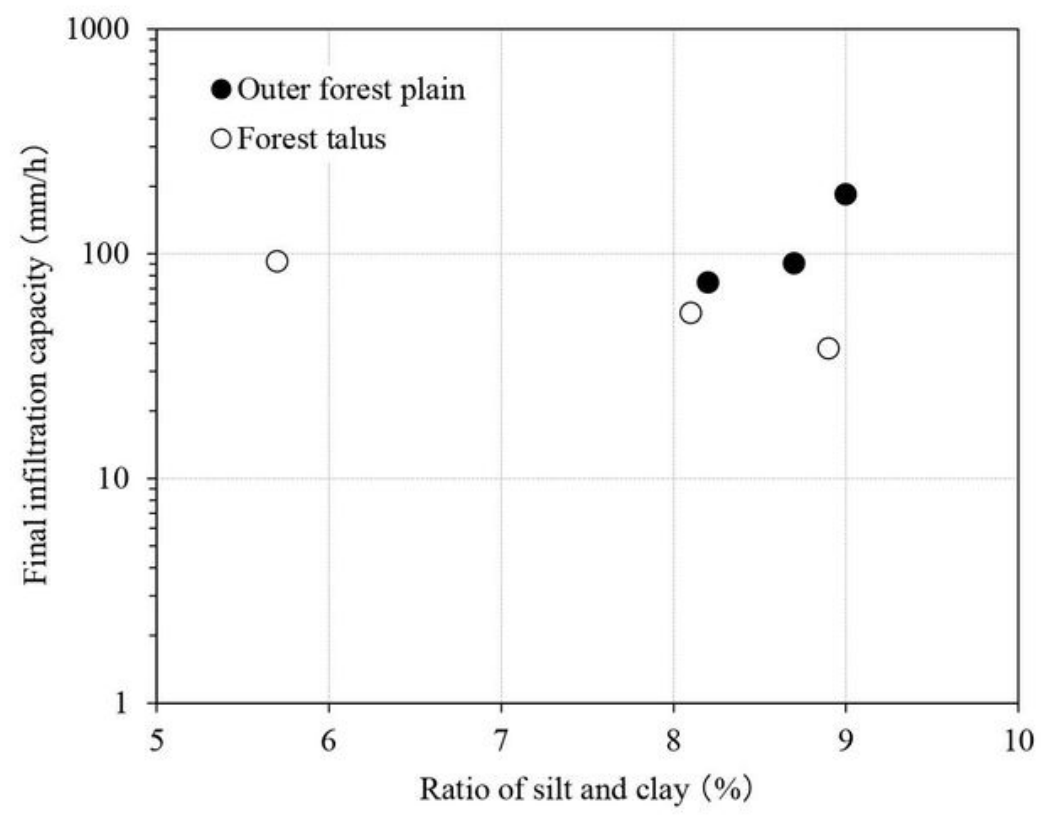

Figure 7

Relationship between D50 and the ratio of silt and clay and the final infilt ration capacity 


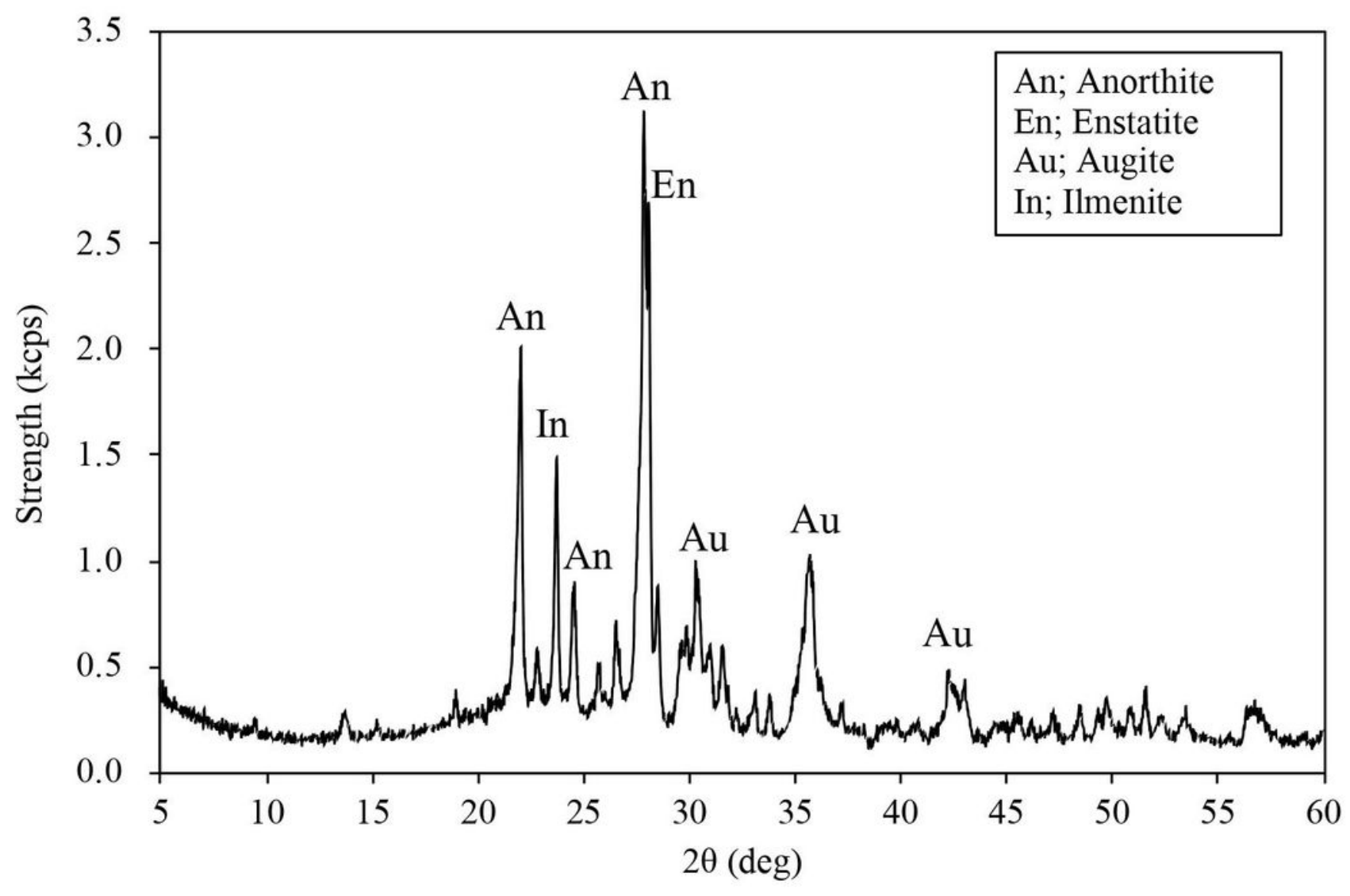

Figure 8

Composition of minerals by X-ray diffraction test

\section{Supplementary Files}

This is a list of supplementary files associated with this preprint. Click to download.

- 01Tableshinmoev2.pdf

- 01Photoshinmoev2.pdf 